\title{
Vendor Role and Responsibility Document
}

National Cancer Institute

\section{Source}

National Cancer Institute. Vendor Role and Responsibility Document. NCI Thesaurus.

Code C115746.

Records describing the tasks and responsibilities of a vendor in a clinical trial. 